\author{
Asad Abbas ${ }^{1}$, Anders Avdic ${ }^{2}$, Kathryn Chang Barker ${ }^{1,3}$, and Peng Xiaobao ${ }^{4}$ \\ ${ }^{1}$ School of Public Affairs, University of Science and Technology of China, No. 96, JinZhai Road, Hefei, 230026, Anhui province, \\ People's Republic of China, +86 13721054064, aabbas@mail.ustc.edu.cn \\ ${ }^{2}$ School of Technology and Business Studies, Dalarna University Campus Borlänge, Röda vägen 3, SE-781 70, Borlänge, Sweden, \\ +4623 778950, aav@du.se \\ ${ }^{3}$ Sultan Qaboos University (SQU), P.O.Box 17, P.C. 123, Muscat, Sultanate of Oman, +968 9614 6809, thekcb@gmail.com \\ ${ }^{4}$ Innovation Management Research Center of School of Public Affairs, University of Science and Technology of China, No. 96, JinZhai Road, Hefei, \\ 230026, Anhui province, People's Republic of China, +86 551 63601445, pxb1982@ustc.edu.cn
}

\title{
KNOWLEDGE TRANSFER FROM UNIVERSITIES TO INDUSTRY THROUGH UNIVERSITY TECHNOLOGY TRANSFER OFFICES
}

Introduction. This paper focuses on knowledge generation and the way in which it is transferred from universities to industry. Most well reputed universities have several departments and university-run enterprises that engage in research. The purpose of these research units is to help universities provide breakthrough innovation through the generation of new knowledge.

Problem Statement. For this we chose to study China's University Technology Transfer Offices (UTTOs) to gather concrete evidence of university knowledge generation for commercial use in industry. The objective of this study is get indepth information about the role of UTTOs in the transfer of such knowledge.

Purpose. The generation of new knowledge contributes to the field of science and technology; in turn, industry can use this knowledge to produce new innovative products or improve existing ones. This study aims to identify the process of knowledge transfer from universities to industry in China.

Materials and Methods. Our study was carried out as a qualitative case study in the Anhui province of China. Data was mainly collected through semi-structured interviews with technology transfer experts working in technology transfer offices. Collected data were analyzed using a knowledge transfer model with six phases: 1) awareness, 2) acquisition, 3) transformation, 4) association, 5) application, and 6) feedback.

Results. In China, universities and their research groups dominate in the generation and commercialization of research results, with UTTOs acting as technology bridges between the two parties, as well as providing legal and business services.

Conclusions. This paper contributes by offering a detailed description of the knowledge transfer process and specifically the role and activities of UTTOs. This research also helps Chinese and international researchers currently carrying out research on the technology transfer process in China.

Keywords: Knowledge transfer, technology transfer, process, university, industry, China.

\section{INTRODUCTION}

The existing literature and current economic trends have demonstrated that knowledge generation and its transfer from universities to industry has been gathering global attention. These trends dynamically change the role played by uni-

(C) ASAD ABBAS, ANDERS AVDIC, KATHRYN CHANG

BARKER, and PENG XIAOBAO, 2018 versities [1], which have become the backbone of government policies. As well as education and training, universities are also engaged in social, economic, research and development activities [2]. Most well-reputed universities have several departments involved in research as well as university-run enterprises [3]. The purpose of these research units is to help universities engage in breakthrough innovation through the generation 
of new knowledge. Such knowledge helps industry to produce new innovative products or improve existing ones. Advancement in technology also changes the role of universities. High ranking universities in the world have established their own university knowledge / technology transfer offices (UTTOs). In China, the central government has set up the State Intellectual Property Office (SIPO), together with provincial intellectual property offices for the implementation of national and regional intellectual property rights (IPR) policies and guidelines at city level. Currently, intellectual property offices operate in thirty regions, including Anhui [4]. The purpose of intellectual property offices is to issue and implement intellectual property rights (IPR) guidelines to technology transfer offices (TTO) to protect the IPR of individuals or research group members and their generated research results. Thus, universities and government have become the innovation hub of national and regional innovation policies aimed at supporting industry.

Governments in both developed and developing countries around the world, especially in China, have put a great deal of effort into reforming their national and regional innovation and economic policies. They have also allocated huge financial resources to identify local requirements and capabilities. To fulfil their innovation requirements, universities and industry need to interact to adopt and implement new technologies [5, 6]. For the last three decades, Chinese government policies, in particular, have focused on economic development. Over this period, the Chinese national GDP has dramatically increased and technology has progressed. Technology transfer has also become an integral part of government research and development policies. These policies provide a platform for interaction between university research groups and industry. They help to identify and share requirements for the generation and transfer of knowledge for commercial use in industry [7, 8]. In China, UTTOs allow universities and their research groups to engage in negotiations for patent licensing, and also to transfer the ownership of commercialized knowledge. Intellectual property offices run by provincial governments help universities and their research groups to understand the requirements of industry and also to support the commercialization process [9]. These offices, together with UTTO activities, serve the research community, handle intellectual property, and establish links between the producers of commercialized knowledge and those who receive that knowledge [10]. The main driver for provincial governments, their intellectual property offices and UTTOs is to accelerate new technologies and enhance social, economic and research activities [11]. The key role of UTTOs is to try to engage university research groups in the generation of new knowledge and the negotiation of intellectual property rights (IPR) and patents before commercialization takes place. In the main, to get funding, public sector universities and their research groups collaborate with local, provincial and central government and industry in China. They do so to produce new knowledge, which the government can use to reform national and regional innovation policies and support industry in terms of greater productivity and profitability.

Government literature states that the city of Hefei in Anhui province is a knowledge-based innovation city. It is also an emerging high-tech industrial development region. Hefei is home to 59 higher education institutes and approximately 34 industries, which produce a wide range of products. Of these, eight are from the high-tech sector and are large producers of good repute, not only within the region, but also nationally and internationally. They are renowned for the wide range and quality of their products. Economic growth trends in Hefei show that in the second half of the last decade, GDP increased by $15.5 \%$. This increase was the result of research, innovation, and industrial development. In Hefei's economic development area, there are now over 100 new high-tech firms. Furthermore, statistics today show a $24 \%$ increase in new high-tech firms compared with 2015. Such economic growth fi- 


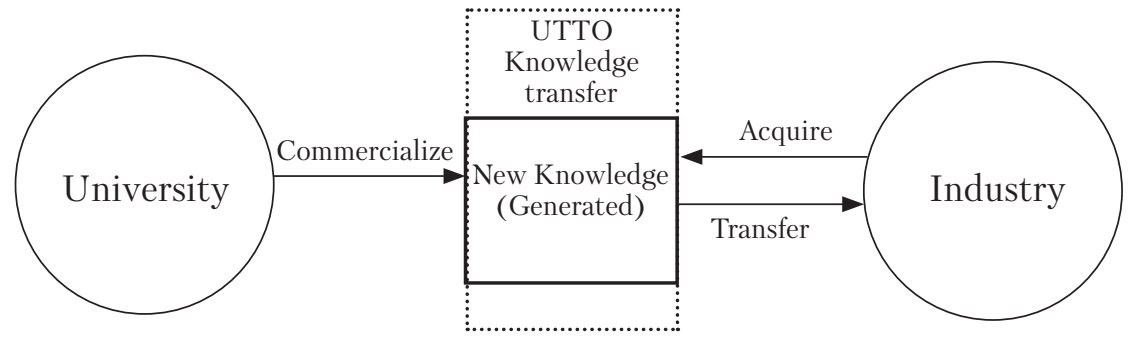

Fig. 1. Theoretical model

gures rank Hefei in $12^{\text {th }}$ position out of 20 cities in the world. In terms of the number of patent applications and approvals made, Hefei ranks the highest of all the cities in Anhui province. Furthermore, Anhui is among the top five provinces in China in terms of effective utilization of university resources to generate new knowledge. Such knowledge helps local industry to benefit from regional economic growth. Both universities and industry can also actively participate in the generation and commercialization process $[12,13]$.

Many studies have already been conducted on knowledge generation and transfer. These have focused on the source and state of knowledge but not on the processes of knowledge generation and transfer to other organizations for innovation and commercial purposes [14, 15]. Thus, our motivation for this study was to identify the process of knowledge transfer from university to the industry. For this reason, we chose to study UTTOs in order to acquire concrete evidence of university knowledge generation for commercial use in industry and to get in-depth information about the role of UTTOs in the transfer of knowledge from university research groups to industry.

This paper is the third in a series that examines the knowledge transfer process from universities to industry. The first paper discussed universitygovernment collaboration for the generation of new knowledge for use in industry, whilst the second discussed industrial strategies to acquire commercialized knowledge from universities. In this study, our focus is on the practical experiences of technology transfer experts, because they are involved in each and every step of the process, right through to the application of knowledge by industry. To this end, we chose to ask the following research question:

What are the routine procedures used by UTTOs to engage in the transfer of knowledge from university research groups to industry for commercial use?

\section{THEORETICAL FRAME OF REFERENCE}

Since the 1950s, university and industry collaboration has been the subject of attention in China. The purpose of such collaboration has been to provide a platform on which universities, industry and government can generate and transfer knowledge (see Fig. 1). In terms of the triple helix, the role of universities is to create knowledge, which is then acquired by industry. The Chinese government acts as a facilitator or bridge between universities and industry. Triple helix collaboration between the stakeholders is thus based on knowledge transfer, research and development, technical services and joint ventures [16-18].

In industry, the concept of knowledge comes from the development of innovation and competitive advantage. Knowledge is either tacit or explicit. Tacit knowledge is intangible, whilst explicit knowledge is tangible. Although both types of knowledge are different in nature, they provide a foundation for continuous interaction between each other [19, 20]. Knowledge is generated by two different methods: 1) 'Mode 1': knowledge is produced by independent universities without collaboration or interaction with other institu- 
tions, and 2) 'Mode 2': knowledge is produced with collaboration between universities, industry and government. Here, interdisciplinary research groups or teams collaborate for a specific period of time to solve specific real world problems [21]. The generation of new knowledge and its successful transfer contributes to production and profits [22]. The transfer of knowledge is a process that is based on a list of sub-processes that start with awareness and finish with the application of knowledge. The list of sub-processes is dynamic and fluid [21]. The role of local government and university intellectual property (IP) offices is to assist the research community, handle IP rights and provide a platform on which universities can form links in order to create commercialized knowledge [10, 24].

Provincial based government IP offices provide guidance to universities and industry, supporting them in their efforts to acquire, commercialize, transfer and implement knowledge without the infringement of local and foreign IP rights [25]. In China, UTTOs are responsible for identifying the results of scientific research and any commercial interests, as well as strategies for their application [26]. Different channels are used to help knowledge transfer, including licensing, foreign direct investment, trade in goods and services, and the movement of personnel [27].

In China, the role of universities and their research groups is to conduct research activities aimed at creating and commercializing knowledge, along with offering basic education training. They also seek to encourage local and national industries in their acquisition of research knowledge. Such research can help them develop innovative products and may give them a competitive advantage $[28,29]$. Industry is a key user of external knowledge. Demands for such knowledge have their foundation in the fulfilment of internal product requirements and processes. Limited resources, manpower and time can slow down the development of new products; thus, industry relies on external resources (such as those offered by universities) to acquire new knowl- edge so that they can fulfil their requirements for developing innovative or improved products [30]. For universities, the purpose of collaboration is to gain more funding, whilst for industry, the aim is to achieve a competitive advantage. Both universities and industry have mutual benefits, namely to improve their infrastructure, techniques and reputation [31]. The role of knowledge transfer is to enhance the capabilities of universities and industry. Universities also have internal rules and procedures for the commercialization of academic research [32]. UTTOs help to connect both universities and industry through face-toface communication to: exchange ideas, promote cooperation, and facilitate the transfer of knowledge. Universities have the relevant knowledge and industry has the capacity to absorb that knowledge [32-34].

\section{METHODOLOGY General research background}

We chose to use a qualitative case study approach so that we could study knowledge and technology transfer in a natural setting and thus gain a more in-depth understanding of the routine procedures involved [35, 36]. Qualitative research enables academics to participate in on-site communication with interviewees and systematically gather interpreted data through face-toface formal or informal dialogues [37-40]. We chose to conduct semi-structured, face-to-face interviews with technology transfer experts from UTTOs involved in routine knowledge transfer procedures.

\section{Sample of research}

The sample selection strategy for our study was purposeful sampling. This is an efficient approach which helps research scholars to select the most productive samples and gather data that is relevant to the research topic [40]. To this end, we were granted permission to conduct interviews by the necessary authorities. We then conducted thirty-five interviews with experts in UTTOs who have the relevant skills and experi- 
ence of applying generated knowledge and the transfer process.

\section{Designed questionnaires}

We designed a list of interview questions based on knowledge transfer - a process model Liyanage et al. [41] (see Fig. 2). Questions were related to awareness, acquisition, transformation, association, and the application of generated knowledge from universities to industry. We also asked questions related to feedback from universities and industry after the transfer of generated knowledge by UTTOs.

In the main, a case study approach tends to focus on the «how» and «why» in interview questions [36]. Our interview questions allowed us to explore the process of knowledge identification in patent licensing (through university research groups) as well as the application of knowledge in industry.

\section{Data Analysis, validity and reliability}

Face-to-face, semi-structured interviews with technology transfer experts were recorded and transcribed into verbatim text and then analyzed using a knowledge transfer model, i.e., a process model [41] (see Fig. 2). According to Liyanage et al. [41, 42], knowledge transfer is based on six core phases: 1) Awareness, 2) Acquisition, 3) Transformation, 4) Association, 5) Application, and 6) Feedback. Similarities between Chinese and Western technology transfer offices and their processes are based on the return on invention investment, IP protection, knowledge generation, evaluation, and the transfer of knowledge for commercial purposes [14]. The first step in knowledge transfer is «awareness», whereby appropriate knowledge is identified. The «acquisition» phase follows, where a receiving organization (industry) has the capabilities to identify their internal requirements but first needs to acquire generated knowledge from external sources. To fulfil their needs, both the source of knowledge (universities) and the receiver (industry) must be willing to share and absorb knowledge. The «transformation» process helps producers (i.e., universities

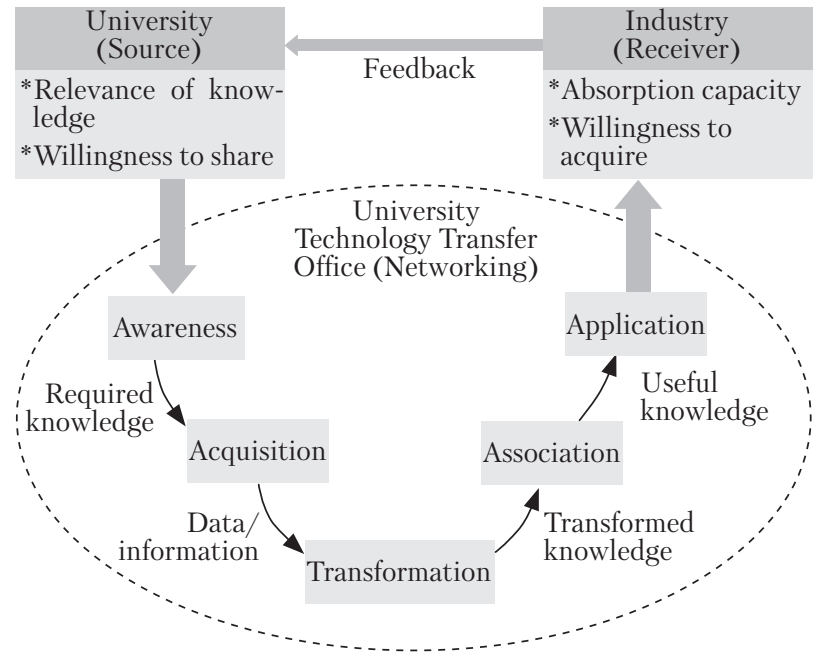

Fig. 2. Conceptual framework [41]

and their research groups) to convert their knowledge into a form that can be used by receiving organizations to produce or improve on existing knowledge and enhance capabilities. For this, university research groups must submit their application along with research results to UTTOs in order to acquire intellectual property rights (IPR) in the form of patents from government IP departments. After being granted a patent or IPR, university research groups can then transfer their generated results to industry. «Association» facilitates receivers (i.e., industry) to identify the key benefits of commercialized knowledge generated by external sources so that they can implement it in their existing system, fulfil their internal requirements and enhance their capabilities. The «application» process enables industry to implement and use knowledge to improve existing products or produce new ones and enhance their development capabilities. Afterwards, the receivers (industry) give feedback about their experience of technology transfer, the link between universities and industry and any benefits accrued are maintained (see Fig. 2).

To ensure the validity and reliability of collected data, it is important to review the existing literature and carry out interviews. These sources of data help to avoid research errors as well as bias [43]. Thus, we used transcribed recorded in- 
terviews and also online data featured on national and provincial government IP websites such as (www.sipo.gov.cn and www.ahipo.gov.cn). These websites gave us both government policies and annual reports related to IP rights.

\section{RESULTS}

For our qualitative case study, we conducted semi-structured, face-to-face interviews with thirty-five individual technology transfer experts, including Directors and Managers from UTTOs located in the capital city of Anhui province between the start of April the middle of August 2017. Each interview lasted for less than one hour. During the interviews, we asked different questions related to awareness, knowledge acquisition, transformation, and association, as well as the application of knowledge and feedback. Our questions were in line with those put forward by Liyanage et al. [41].

Below, we describe six different categories. We begin each category with a definition, followed by quotes from interviewees and a more in-depth explanation (see Fig. 3). We finish each section with a summary.

\section{Awareness}

The knowledge transfer process begins with awareness. Source organizations initiate the knowledge transfer process for receiving organizations «by identifying new research fields, including academic research trends, and industrial requirements in their respective region». To do this, academics and their research groups «attend local and international academic research conferences, symposiums, government and official industrial meetings, and read and publish research articles». To «identify the worth of university scientific research results and search potential users», UTTOs analyzes their «appropriateness and market value». Newly generated knowledge can only be protected by IPR law in the form of patent licensing. For patent licensing, «university research groups must visit UTTOs with a new idea such as scientific research topic or scientific research results». They discuss with «TTO experts the appropriateness and its mar- ket value». According to TTO experts, «before the start of any patent application process, new ideas or research results are analyzed to determine whether or not they are innovative and original». Experts in UTTOs involved check the «market value in term of cost and profit and also suitable users». After discussion with the university, «TTO experts prepare a business plan for a patent license and technology transfer». University research groups «only focus on the scientific research and their results»; thus, they are not familiar with «business development plans and legal processes such as intellectual property law and technology transfer». UTTO offices have teams of experts with «practical skills, as well as experience related to business and law». They are already in regular contact with local government and industry in their respective region and, consequently, are aware of industrial requirements and the latest market trends for technology, as well as government policies. In the main, TTO experts «gain an awareness of newly generated knowledge through official meetings, seminars, and forums with university professors». They also identify requirements by attending relevant «meetings, activities, seminars, and forums arranged by government and industry». These kinds of activities provide a platform on which UTTOs can identify industrial requirements, university-generated research results, government policies related to economic and law. They can also build relationships with all stakeholders such as universities, industry and government.

\section{Acquisition}

During the acquisition process, industry (i.e., the receiving organization) first identifies their internal requirements through «their short-and long-term business development plan, problem identification during product development, and knowledge of customer requirements and market technology trends». Once identified, industry can fulfil these internal requirements by adopting innovative product development using external sources such as universities. Industry then contacts UTTOs to help them source external knowledge 


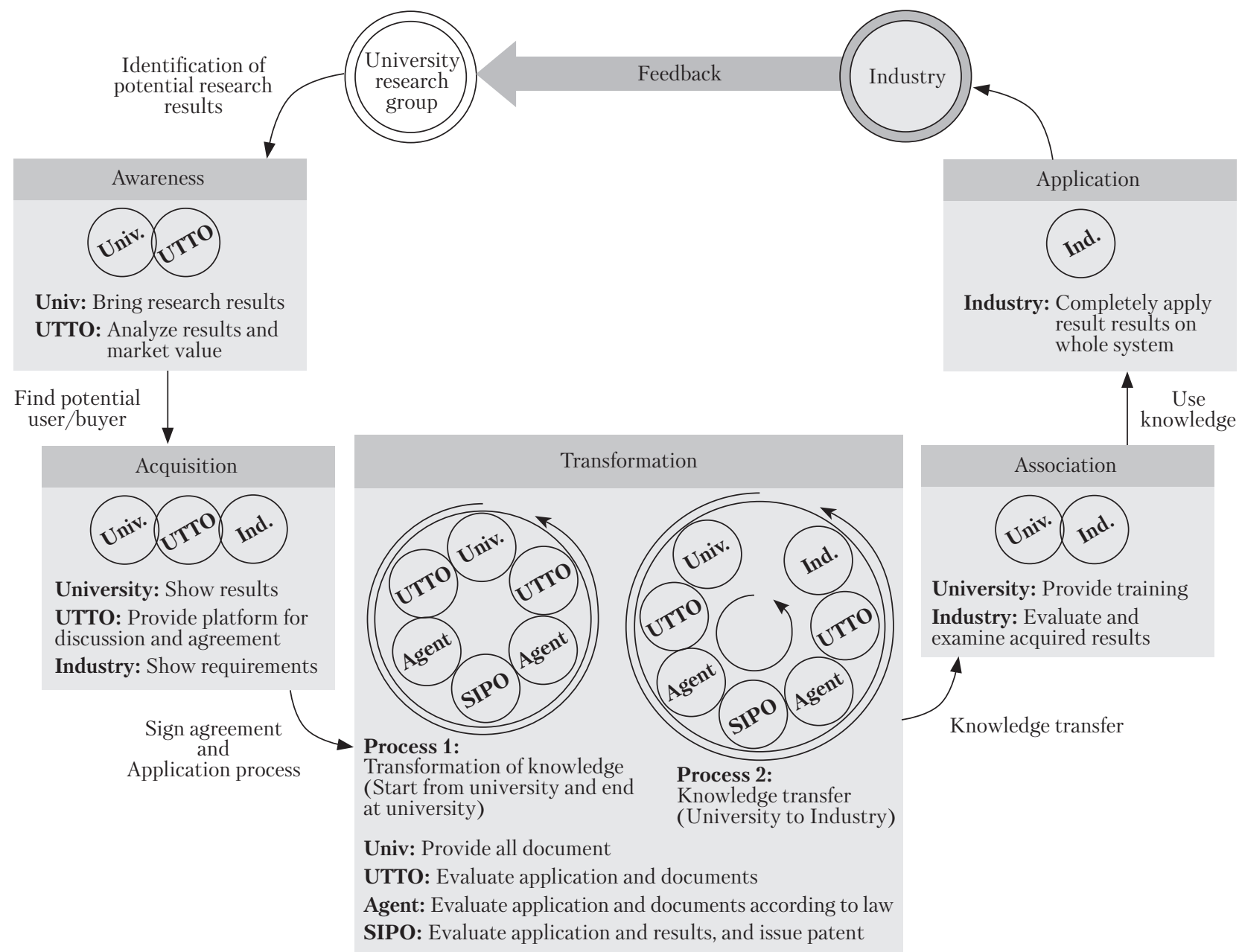

Fig. 3. The knowledge transfer process - from university research group to industry

from such organizations as universities. In this way, by seeking a reliable, suitable and long term partnership with universities, industry can acquire new knowledge for the development of new or existing products with minimal effort and resources. Industry and UTTOs «maintain contact through emails, telephonic calls, and meetings». Industrial experts also seek «information about university experts and their fields of expertise, study research results in published papers and ongoing research projects, and identify skilled research teams through university websites, academic journals and published conference papers, and government-arranged official forums and expos». UTTOs have their own links with «academics in universities and research groups through academic meetings and activities», giving them access to information about their ongoing research and latest results. UTTOs arrange «meetings and invite both university research groups and industry representatives to share their requirements and results with each other». Successful negotiations between both parties (universities and industry), «result in the signing of contracts or agreements for the acquisition and transfer of generated knowledge from producers (universities) to receivers (industry)».

\section{Transformation}

The transformation process begins after the acquisition process, and helps producers (universi- 
ties) to convert their research results into a useful form. For example, as part of this process, a university academic may contact his or her university TTO to seek technical support in terms of patent licensing. The UTTO then arranges meetings with the academic and performs an analysis of their «research results» for analysis. The analysis considers the results in terms of «novelty» and «market value». The university academic and UTTO experts then «discuss and prepare a business plan». According to TTO experts, «the transformation of generated knowledge is based on research topic, research and development, the formation of scientific research, technology transfer, and the whole process of industrialization». A UTTO office's responsibility is to «perform standard procedures such as check the applicationalongwithgivenresults». Thetransformation of new knowledge takes place through «patent application, a business plan, and detailed documents of research results (including all technical details and experimental data)». After carefully reviewing the patent application, the UTTO office finds a government-authorized agent who is responsible for handling patent applications. The agent checks «the application in detail, together with the attached documents in accordance with law». They then submit an application to the State Intellectual Property Office (SIPO) for the issuance of a patent. After a successful evaluation of the application by SIPO, «a patent licensing is granted to that university and the academic is eligible to transfer their knowledge through technology transfer with industry».

\section{Association}

The process of knowledge association enables receiving organizations (industry) to identify the benefits of acquiring knowledge in the form of a patent from producers, both before and after implementing that knowledge. Industry's motivation for acquiring new knowledge from external sources «in the form of patents is to fulfil their internal needs and thus enhance their innovative product development capabilities». After the sig- ning of a contract in which «universities and $a$ particular company agree to collaborate and engage in the knowledge transfer process», the UTTO office "starts the patent application process». Once SIPO has agreed to issue a patent, the UTTO office invites both parties to discuss the knowledge transfer process in accordance with the signed contract. The contract clearly mentions the: «definition and scope of technology, amount, payment and effective date, rights and liability». During the association of «research results, members of the university research group give training to the industrial technical staff through workshops and short-term training courses, so that they can apply a university research results to existing industrial systems». Sometimes, industry hires «third party organizations to issue certificates to verify the validity of research results or technology in an existing industrial system».

\section{Application}

During the application process, receiving organizations implement new knowledge into their existing systems, enabling them to enhance their product development capabilities in terms of introducing new products or improving those that already exist. Before the application process, industrial experts examine and authenticate research results by applying them in the real environment. Once the verification certificate has been issued, and after completion of technical staff training by university academics and research groups, receiving organizations fully implement the acquired knowledge into their existing systems in order «to fulfill their innovative product development needs and also the product requirements of customers».

\section{Feedback}

Feedback is based on dialogue between producers and receiving organizations during the acquisition and transfer of knowledge. Such dialogue is carried out using formal or informal platforms, such as «UTTOs, industrial or academic seminars, industrial meetings organized by local 
government, and industrial expos». These platforms help them to identify any research and also present their research results. Here, government and UTTOs act as a bridge between universities and industry. From creating awareness to the application of generated knowledge, UTTOs play a central role. After successful knowledge transfer and integration, the receiving organization gives feedback to the producer. Feedback helps both parties to remain in contact during the collaboration process so that they can continue to fulfil each other's needs.

\section{DISCUSSION}

In this section, we discuss how the knowledge transfer process begins with awareness in universities and their research groups and is completed when generated knowledge is used in industry and feedback has been given. In order to answer our research question, we arranged face-to-face interviews with technology transfer experts, because they are involved in the knowledge transfer process. During these sessions, technology transfer experts gave detailed information about the process of knowledge transfer from universities and their research groups to industry in China in general and, specifically, Anhui province.

In China, most university academics and research groups are not familiar with the potential market value of their research results. Awareness is the result of knowledge use [44]. Thus, university academics and members of research groups attend local and international conferences, and seminars organized by government and industry to gain awareness about the latest fields of research, current and future government policies relating to research and development, and any industrial requirements. After the acquisition of information about market research trends, academics and research groups bring their research results to their local UTTOs. They discuss their research outcomes with the TTO experts in order to validate their research results and evaluate their market value in terms of cost and return and also find a potential user or buyer. After re- view, UTTO offices help design a business research plan.

Universities want to financially support their own research through technology transfer activities and the commercialization of generated research results [45]. To bring this about, academics attend seminars, conferences, and forums organised by local government departments, UTTOs, and industrial $\mathrm{R} \& \mathrm{D}$ departments. The stakeholders present their results, and consider market demands, future development plans, and policies related to social, economic and research development. In order that everyone can understand each other's requirements and enhance cooperation, short-term or long-term agreements are signed. The basic components of these contracts are: definition of the technology, type, price, mode of payment, and liability. Direct universityindustry knowledge transfer is dominant [46]. Here, universities have the relevant skills and generated knowledge, whilst industry has the absorption capacity and UTTOs can offer services such as technology bridging, and government links. An example of university-industry technology transfer through UTTOs is the cancer-related biological medicine patent transferred by a UTTO in Anhui province to the Anhui Fengyuan Pharmaceutical Limited (Stock: 000153) in 2015, valued at 100 million RMB. In the same year, another patent for cancer-related biological medicine was transferred to a public company, Anhui BBCA Pharmaceutical.

Thus, universities create scientific knowledge and its ontology is that it is based on codified knowledge in the form of a patent or publications [46]. UTTOs help university research groups to protect their generated knowledge through intellectual property (IP) law. In the US, $73 \%$ of papers cited in industry patents have been published by university research groups [25]. In China, UTTO offices help university academics and their research group to prepare patent applications. Experts thoroughly review applications and any attached documents in accordance with their standard procedure and IP law. If applica- 
tions meet the basic requirements in terms of the law and application checklists, UTTOs find suitable agents within in their region or further afield. The responsibilities of agents are to review applications and documents in accordance with SIPO rules and regulations and Chinese IPR law. An agent is an authorized firm (such as DeHeng Intellectual Property Law, and Beijing-Sino Tech Patent Agent Ltd), who can pursue patent applications. UTTOs do not charge universities an application fee for filling patent applications, although they do pay 3.000 to 5.000 RMB to agents from any generated university revenue. Agents submit applications to SIPO either online or by mail. SIPO experts thoroughly review each application dossier whether or not it is complete. If complete, then a list of anonymous experts is assigned to the evaluation of attached research results in accordance with standard procedure and law. After the successful evaluation of results, permission is granted for the issuance of a patent. During 2016, some 2,415,463 patent applications were filed with SIPO, including 131,807 applications from Anhui province [4, 47].

The actual owners of generated knowledge are university academics or research groups; however, in essence, this knowledge belongs to both universities and the nation. SIPO informs agents about their decision either online or by mail. Agents then forward patents and related documents to UTTOs. University can then commercialize their results through knowledge transfer to any interested parties, i.e., industry. Industry needs new knowledge for the development of innovative products $[28,48]$. With contracts already in place, universities again submit applications to SIPO through UTTOs in order to transfer IP rights to industry. Knowledge resources enhance the capabilities of university and industry through the generation and transfer of knowledge taking into account standard university rules and regulations [32, 49]. Meanwhile, industry integrates university research results into their real environment for authentication and examination purposes. Once successfully exe- cuted and authenticated, university research groups are then responsible for arranging workshops and training for technical staff in industry who are responsible for maintaining the production line. Successful association and training facilitates the application of acquired knowledge into existing industrial systems in order to gain benefits in the form of innovative product development or the improvement of existing products and systems.

After the successful completion of all processes, feedback is given by industry about implementation. The exchange of ideas and the enhancement of cooperation helps industry to identify absorption capacity, and create further university-industry links [32-34]. Feedback facilitates both parties to further enhance collaboration. In addition, UTTOs are encouraged to engage with university research groups and industry to generate and transfer knowledge. Regional governments may also choose to reform their economic, social and research development policies to promote education, research, business, technology transfer, and innovation.

\section{CONCLUSION}

In conclusion, in China, universities and their research groups dominate in the generation and commercialization of research results, with UTTOs acting as technology bridges between the two parties, as well as providing legal and business services. In China, both central and provincial government intellectual property offices make policies and guidelines available to UTTOs. Thus, UTTOs: (a) follow government's IP guidelines and support stakeholders such as universities and industry in terms of their awareness of the potential for the commercialization of research results; (b) make sure the rights of both producers and users of knowledge are protected; (c) provide a platform for university research groups on which they can share their results with industry; (d) identify internal product development requirements in industry and select the university research results that best fulfil their innovative 
product development requirements; (e) secure research results in accordance with Chinese government rules and regulations, and local and foreign laws, and find suitable industrial partners to enable the transfer of knowledge within their respective region. This research contributes to a greater understanding of Chinese and international research into the Chinese technology transfer process.

\section{Limitation and future study}

The limitation of this study is that we focused on only one province in China. Furthermore, all the interviewees were from UTTOs based in Anhui's capital city, Hefei. For data collection, we first sought permission for interviews and then arranged for them to take place. The organization of face-to-face interviews with Chinese UTTO officials was not an easy task, because some of them were not fluent in English and others had busy official schedules. During the interview sessions, we engaged the assistance of a language translator in case of any misunderstanding of the English language.
This study will help future researchers to compare developed and developing regions of China on the basis of technology transfer. For further study, it would also be helpful to carry out empirical research to explore in-depth information about influencing factors on the Chinese knowledge transfer processes and the sharing of knowledge between universities and industry according to central and regional government guidelines.

Acknowledgement the first author acknowledges the CAS-TWAS Presidents' Fellowship for financial support. This research is also supported by the Natural Science Foundation of Anhui under Grant Nos. 1508085QG143, and the Philosophy and Social Science Foundation of Anhui under Grant Nos. AHSKZ2016D07. We are thankful to Liya Wang, PhD student at USTC School of Public Affairs for helping us during data collection as language translator. We also appreciate the precious time and participation given by technology transfer experts in the interview sessions.

\section{REFERENCES}

1. Gao, X., Song, W., Peng, X., Song, X. (2014). Technology transferring performance of Chinese universities: Insights from patent licensing data. Advances in Applied Sociology, 4(12), 289.

2. Loi, M., Di Guardo, M. C. (2015). The third mission of universities: An investigation of the espoused values. Science E Public Policy, 42(6), 855-70.

3. Zhou, C., \& Peng, X.-M. (2008). The entrepreneurial university in China: nonlinear paths. Science \& Public Policy, 35(9), 637-646.

4. SIPO. State Intellectual Property Office of P. R. China. 2017. URL: http://www.sipo.gov.cn (Last accessed: 11.01.2017).

5. Chan, L., Daim, T. U., Kocaoglu, D. F. (2016). National technology planning: a case study on the biopharmaceutical industry in China. Hierarchical Decision Modeling, 183-96.

6. Zhang, Y., Zhou, X., Porter, A. L., Gomila, J. M. V., Yan, A. (2014). Triple Helix innovation in China's dye-sensitized solar cell industry: hybrid methods with semantic TRIZ and technology roadmapping. Scientometrics, 99(1), 55-75.

7. Gertner, D., Roberts, J., Charles, D. (2011). University-industry collaboration: a CoPs approach to KTPs. Journal of Knowledge Management, 15(4), 625-47.

8. Liu, H., Jiang, Y. (2001). Technology transfer from higher education institutions to industry in China: nature and implications. Technovation, 21(3), 175-88.

9. O'kane, C., Mangematin, V., Geoghegan, W., Fitzgerald, C. (2015). University technology transfer offices: the search for identity to build legitimacy. Research Policy, 44(2), 421-37.

10. Martín-Rubio, I., Andina, D. (2016). University knowledge transfer offices and social responsibility. Administrative Sciences, 6(4), 20. 
11. Siegel, D. S., Waldman, D. A., Atwater, L. E., Link, A. N. (2003). Commercial knowledge transfers from universities to firms: Improving the effectiveness of university-industry collaboration. Journal of High Technology Management Research, 14(1), 111-33.

12. Gao, X., Chen, Y., Song, W., Peng, X., Song, X. (2015). Regional University-Industry Knowledge Flow: A Study of Chinese Academic Patent Licensing Data. Open Journal of Social Sciences, 3(02), 59.

13. Hefei-China. Hefei overview. 2017. URL: http://www.hefei.gov.cn/english/ (Last accessed: 11.01.2017)

14. Alipour, F., Idris, K., Karimi, R. (2011). Knowledge creation and transfer: Role of learning organization. International Journal of Business Administration, 2, 61.

15. Miesing, P., Tang, M. (2017). Technology transfer institutions in China: A comparison of value chain and organization structure perspective. Chapter 3 in D. Libaers and D. Dunlap (eds.), University Technology Transfer and Academic Entrepreneurship (World Scientific Publishing Co.) Vol. 1 in The World Scientific Reference on Innovation Series Edited by D. Siegel.

16. Du Plessis, M. (2007). The role of knowledge management in innovation. Journal of Knowledge Management, 11(4), $20-9$.

17. Inkpen, A. C. (1996). Creating knowledge through collaboration. California Management Review, 39(1), 123 -40.

18. Wu, W. (2007). Cultivating research universities and industrial linkages in China: The case of Shanghai. World Development, 35(6), 1075-1093.

19. Bellini, A., Aarseth, W., Hosseini, A. (2016). Effective knowledge transfer in successful partnering projects. Enrgy Proced., 96, 218-28.

20. Nonaka, I., Toyama, R. (2003). The knowledge-creating theory revisited: knowledge creation as a synthesizing process. Knowledge Management Research E Practice, 1(1), 2-10.

21. Hsu, D. W., Shen, Y.-C., Yuan, B. J., Chou, C. J. (2015). Toward successful commercialization of university technology: Performance drivers of university technology transfer in Taiwan. Technological Forecasting and Social Change, 92, 25-39.

22. Qian, H., Jung, H. (2017). Solving the knowledge filter puzzle: absorptive capacity, entrepreneurship and regional development. Small Business Economics, 48(1), 99-114.

23. Gilbert, M., Cordey-Hayes, M. (1996). Understanding the process of knowledge transfer to achieve successful technological innovation. Technovation, 16(6), 301-312.

24. Swamidass, P. M., Vulasa, V. (2009). Why university inventions rarely produce income? Bottlenecks in university technology transfer. The Journal of Technology Transfer, 34(4), 343-363.

25. Freitas, I. M. B., Marques, R. A., e Silva, E. M. d. P. (2013). University-industry collaboration and innovation in emergent and mature industries in new industrialized countries. Research Policy, 42(2), 443-453.

26. Eneh, O. C. (2010). Technology transfer, adoption and integration: a review. Journal of Applied Sciences, 10(16), $1814-1819$.

27. De La Tour, A., Glachant, M., M ni re, Y. (2011). Innovation and international technology transfer: the case of the Chinese photovoltaic industry. Energy Policy, 39(2), 761-770.

28. Abramo, G., D’Angelo, C. A., Solazzi, M. (2011). The relationship between scientists' research performance and the degree of internationalization of their research. Scientometrics, 86(3), 629-643.

29. Sellenthin, M. O. (2009). Technology transfer offices and university patenting in Sweden and Germany. Journal Technol Transfer, 34(6), 603-620.

30. Sherwood, A. L., Covin, J. G. (2008). Knowledge acquisition in university-industry alliances: An empirical investigation from a learning theory perspective. Journal of Product Innovation Management, 25(2), $162-179$.

31. Aldrich, H. E. (2012). The emergence of entrepreneurship as an academic field: A personal essay on institutional entrepreneurship. Research Policy, 41(7), 1240-1248.

32. Perkmann, M., Tartari, V., McKelvey, M., Autio, E., Brostrom, D’Este, P., Sobrero, M. (2013). Academic engagement and commercialisation: A review of the literature on university-industry relations. Research Policy, 42(2), 423-442.

33. Bishop, K., D’Este, P., Neely, A. (2011). Gaining from interactions with universities: Multiple methods for nurturing absorptive capacity. Research Policy, 40(1), 30-40.

34. Ben Letaifa, S., Rabeau, Y. (2013). Too close to collaborate? How geographic proximity could impede entrepreneurship and innovation. Journal of Business Research, 66(10), 2071-2078.

35. Houghton, C., Casey, D., Shaw, D., Murphy, K. (2013). Rigour in qualitative case-study research. Nurse Researcher, 20(4), 12-17.

36. Yin, R. K. (2013). Case study research: design and methods. Sage publications.

37. Baxter, L., Hughes, C., Tight, M. (1998). Academic career handbook. McGraw-Hill Education (UK). 
38. Johnson, R. B., Onwuegbuzie, A. J. (2004). Mixed methods research: a research paradigm whose time has come. Educational Researcher, 33(7), 14-26.

39. Malterud, K. (2001). Qualitative research: standards, challenges, and guidelines. Lancet, 358(9280), 483-488.

40. Williams, C. (2011). Research methods. Journal of Business $\mathcal{E}$ Economics Research, 5(3), 65-72.

41. Liyanage, C., Elhag, T., Ballal, T., Li, Q. P. (2009). Knowledge communication and translation - a knowledge transfer model. Journal of Knowledge Management, 13(3), 118-131.

42. Liyanage, C., Elhag, T., Ballal, T. (2012). Establishing a connection between knowledge transfer and innovation diffusion. Journal of Knowledge Management Practice, 13(1).

43. Abbas, A., Faiz, A. (2013). Usefulness of digital and traditional libraries in higher education. International Journal of Services Technology and Management, 19(1-3), 149-61.

44. Ogata, H., Yano, Y. (2000). Combining knowledge awareness and information filtering in an open-ended collaborative learning environment. International Journal of Artificial Intelligence in Education, 11, 33-46.

45. Etzkowitz, H., Klofsten, M. (2005). The innovating region: toward a theory of knowledge based regional development. R\&D Management, 35(3), 243-255.

46. Baba, Y., Shichijo, N., Sedita, S. R. (2009). How do collaborations with universities affect firms' innovative performance? The role of "Pasteur scientists" in the advanced materials field. Research Policy, 38(5), 756-764.

47. AHIPO. Anhui Intellectual Property Office. 2017. URL: http://www.ahipo.gov.cn (Last accessed: 11.01.2017).

48. Vaivode, I. (2015). Triple helix model of university-industry-government cooperation in the context of uncertainties. Procedia-Social and Behavioral Sciences, 213, 1063-1067.

49. Ensign, P. C., Lin, C-D., Chreim, S., Persaud, A. (2014). Proximity, knowledge transfer, and innovation in technology-based mergers and acquisitions. International Journal of Technology Management, 66(1), 1-31.

Received 02.11.17

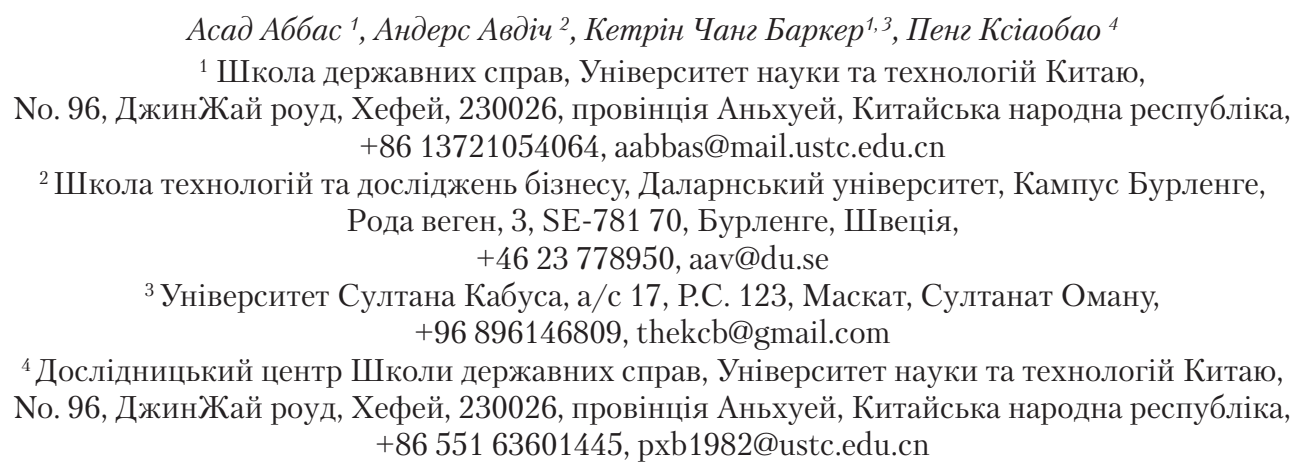
ПЕРЕДАЧА ЗНАНЬ ВІД УНІВЕРСИТЕТІВ У ПРОМИСЛОВИЙ СЕКТОР
ЧЕРЕЗ УНІВЕРСИТЕТСЬКІ ДЕПАРТАМЕНТИ ПЕРЕДАЧІ ТЕХНОЛОГІЙ

Вступ. Висвітлено питання генерації знань та способу ї передачі від університетів у промисловість. Найвідоміші університети мають кілька департаментів та підприємств, які займаються дослідженнями. Мета цих підрозділів полягає в тому, щоб допомогти університетам забезпечити інноваційні рішення шляхом створення нових знань.

Проблематика. Генерація нових знань сприяє розвитку галузі науки та техніки, які, у свою чергу, використовуються промисловістю для виробництва нових інноваційних продуктів або вдосконалення вже існуючих. На прикладі роботи департаментів трансферу технологій (ДТТ) в університетах Китаю вивчено роботу та зібрано конкретні факти генерації знань для комерційного використання в промисловості.

Мета. Отримання детальної інформації про роль ДТТ у передачі знань від університетів до промисловості в Китаї.

Матеріали та методи. Дослідження проведено в китайській провінції Аньхой (Аньхуей). Збір даних виконували за допомогою напівструктурованих інтерв’ю з фахівцями з передачі технологій, які працюють в офісах департаментів передачі технологій. В подальшому їх аналізували за допомогою моделі передачі знань, яка передбачає шість етапів: поінформованість, придбання, перетворення, зв'язок ідей, застосування та зворотній зв’язок.

Результати. Університети Китаю та їх дослідницькі групи домінують у виробництві та комерціалізації результатів досліджень, а ДТТ відіграють роль технологічних мостів між двома сторонами, а також надають юридичні та бізнес-послуги. 
Висновки. Стаття містить детальний опис процесу передачі знань та, зокрема, висвітлює роль та діяльність ДТТ Китаю, що може бути корисним китайським та міжнародним науковцям у проведенні досліджень процесу передачі технологій.

Ключові слова: передача знань, передача технологій, процес, університет, промисловість, Китай.

\author{
Асад Аббас ${ }^{1,}$ Андерс Авдич ${ }^{2}$, Кетрин Чанг Баркер ${ }^{1,3}$, Пенг Ксиаобао ${ }^{4}$ \\ ${ }^{1}$ Школа государственных дел, Университет науки и технологий Китая, \\ No. 96, ДжинЖай роуд, Хэфэй, 230026, провинция Аньхуэй, Китайская народная республика, \\ +8613721054064, aabbas@mail.ustc.edu.cn \\ ${ }^{2}$ Школа технологий и исследований бизнеса, Даларнский университет, \\ Кампус Бурленге, Рода веген, 3, SE-781 70, Бурленге, Швеция, \\ +4623 778950, aav@du.se \\ ${ }^{3}$ Университет Султана Кабуса, а/с 17, Р.Я. 123, Маскат, Султанат Омана, \\ +96 896146809, thekcb@gmail.com \\ ${ }^{4}$ Исследовательский центр Школы государственных дел, Университет науки и технологий Китая, \\ No. 96, ДжинЖай роуд, Хэфэй, 230026, провинция Аньхуэй, Китайская народная республика, \\ +8655163601445, pxb1982@ustc.edu.cn

\section{ЧЕРЕЗ УНИВЕРСИТЕТСКИЕ ДЕПАРТАМЕНТЫ ПЕРЕДАЧИ ТЕХНОЛОГИЙ} \\ ПЕРЕДАЧА ЗНАНИЙ ОТ УНИВЕРСИТЕТОВ В ПРОМЫШЛЕННЫЙ СЕКТОР
}

Введение. Раскрыто вопрос генерации знаний и способа их передачи от университетов в промышленность. Самые известные университеты имеют несколько департаментов и предприятий, которые занимаются исследованиями. Цель этих подразделений лежит в том, чтобы помочь университетам обеспечить инновационные решения путем создания новых знаний.

Проблематика. Генерация новых знаний способствует развитию отрасли науки и техники, которые, в свою очередь, используются промышленностью для производства новых инновационных продуктов или усовершенствования уже существующих. На примере работы департаментов трансфера технологий (ДТТ) в университетах Китая изучено работу и собрано конкретные факты генерации знаний для коммерческого использования в промышленности. в Китае.

Цель. Получение детальной информации о роли ДТТ в передаче знаний от университетов к промышленности

Материалы и методы. Исследование проведено в китайской провинции Аньхой (Аньхуей). Сбор данных производили с помощью полуструктурированных интервью специалистов с передачи технологий, которые работают в офисах департаментов передачи технологий. В дальнейшем их анализировали с помощью модели передачи знаний, которая предусматривает шесть этапов: информированность, получение, преобразование, связь идей, использование и обратная связь.

Результаты. Университеты Китая и их исследовательские группы доминируют в производстве и коммерциализации результатов исследований, а ДДТ играют роль технологических мостов между двумя сторонами, а также предлагают юридические и бизнес-услуги.

Выводы. Статья содержит детальное описание процесса передачи знаний и, в частности, раскрывает роль и деятельность ДТТ Китая, что может быть полезным китайским и международным ученым при проведении исследований процесса передачи технологий.

Ключевые слова: передача знаний, передача технологий, процесс, университет, промышленность, Китай. 